Abstract

\title{
Monitoring in the Cultivation of Tomatoes Under Cover in Poland and the Netherlands ${ }^{+}$
}

\author{
Aleksanda Raut* and Beata Borowiak-Sobkowiak \\ Department of Entomology and Environmental Protection, Poznan University of Life Sciences, Dąbrowski- \\ ego 159, 60-594 Poznań. \\ * Correspondence: olaraut@gmail.com \\ † Presented at the 1st International Electronic Conference on Entomology (IECE 2021), 1-15 July 2021; \\ Available online: https://iece.sciforum.net/.
}

Citation: Raut, A.; Borowiak-

Sobkowiak, B. Monitoring in the Cultivation of Tomatoes Under Cover in Poland and the Netherlands, in Proceedings of the 1st International Electronic Conference on Entomology, 1-15 July 2021, MDPI: Basel, Switzerland, doi:10.3390/IECE-10684

Published: 15 July 2021

Publisher's Note: MDPI stays neutral with regard to jurisdictional claims in published maps and institutional affiliations.

Copyright: (C) 2021 by the authors. Submitted for possible open access publication under the terms and conditions of the Creative Commons Attribution (CC BY) license (http://creativecommons.org/licenses /by/4.0/).

\begin{abstract}
The most important pests in the cultivation of greenhouse tomatoes in Europe include stinging and sucking insects, caterpillars of butterflies, predatory bugs and mites. In order to diagnose the species found in Poland and the Netherlands, pests were monitored in the 2018-2020 growing seasons. For this purpose, the Dutch cultivation of red tomatoes of the Merlice variety and the Polish cultivation of raspberry tomatoes of the Tomimaru Muchoo variety were used. The pests were caught on yellow sticky plaques and pheromone traps during weekly monitoring. There were differences in the pest species composition in both countries. Although the vetting was aimed at identifying the presence of the tomato leaf miner Tuta absoluta, it turned out that the Netherlands was dominated by Chrysodeixis chalcites and Nesidiocoris tenuis, which until recently were a biological weapon in the fight against the moth. In Poland, the greatest threat to tomato cultivation turned out to be the tomato leaf miner and the tomato rust mite Aculops lycopersici. The performed task allowed for drawing two main conclusions: the pest species occurring in the Netherlands in 2018, have never been recorded in Poland before. Monitoring from 2020 showed the first occurrence of these species also in this country. The second conclusion was the difference in the colonization of tomato leaf miner on both tomato cultivars.
\end{abstract}

Keywords: pest; tomatoe; yellow sticky plaques; Poland; Netherlands 